\title{
Notes on the Brazilian Crisis of 1997-991
}

\author{
Notas sobre a crise brasileira de 1997-1999
}

FRANCISCO L. LOPES ${ }^{2}$

RESUMO: Este artigo trata da crise brasileira de 1997-98 que levou à flutuação cambial de janeiro de 1999. Começa por mostrar como a política cambial evoluiu desde o Plano Real de 1994 e como o regime cambial se tornou uma questão crítica quando a crise começou em 1997. Ele discute a política monetária durante a crise, o programa do FMI, a banda diagonal endógena e a decisão de flutuar como uma alternativa aos controles de capital e inadimplência. Este drama de cinco anos terminou surpreendentemente bem com uma flutuação benigna, mas é útil conhecer seus detalhes, com a mistura usual de debate econômico, confrontos de personalidade e fatalidade histórica.

PALAVRAS-CHAVE: Crise brasileira de 1997-98; política de taxa de cambio; Plano Real de 1994; banda diagonal endógena; decisão de flutuar.

ABSTRACT: This paper deals with the Brazilian crisis of 1997-98 that lead to the exchange rate floating of January 1999. It starts by showing how exchange rate policy evolved since the Real Plan of 1994 and how the exchange rate regime became a critical issue when the crisis started in 1997. It discusses monetary policy during the crisis, the IMF program, the endogenous diagonal band and the decision to float as an alternative to capital controls and default. This five-year drama ended surprisingly well with a benign float, but it is useful to know its details, with the usual mix of economic de- bate, personality clashes and historical fatality.

KEYWORDS: Brazilian crisis of 1997-98; exchange rate policy; Real Plan of 1994; endogenous diagonal band; decision to float.

JEL Classification: N16; F0; E4.

\footnotetext{
${ }^{1}$ Paper presented at the conference "Critical Issues in financial Reform; Latin American/Caribbean and Canadian Perspectives”, The Munk Centre for International Studies, University of Toronto, June 2000. Helpful comments from Persio Arida, Edmar Bacha, Albert Berry, Luiz Carlos Bresser-Pereira and José Roberto Mendonça de Barros are acknowledged.

${ }^{2}$ Macrométrica Sistemas Ltda., Rio de Janeiro/RJ, Brasil. E-mail: chlopes@macrometrica.com.br.
} 


\section{INTRODUCTION}

In July 1994, Brazil once more started a new stabilization program, after a long series of failures. ${ }^{3}$ It aimed at curbing the chronic inflation that had been undermining the economy for the past two decades. But the Real Plan was such an undeniable success that finance minister Fernando Henrique Cardoso, its main leader, won the presidential election of October 1994 (Bacha 2001, Gordon 2001).

The Real plan relied heavily on exchange rate over-valuation and this became a critical issue when the Asia crisis hit in 1997. Things did not get better in 1998, when Russia defaulted in its external debt. Though Brazil had to adopt very drastic monetary policy measures, Cardoso managed to get reelected for a second term starting in 1999. By that time, however, the pressure on the Brazilian exchange rate regime had become almost unbearable and the country had to choose between floating its exchange rate or going back to old fashioned capital controls, with the inevitable consequence of default on its external debt. This five years drama ended surprisingly well with a benign float, but its details, with the usual mix of economic debate, personality clashes and historical fatality, deserves to be recounted. This essay benefits from the fact that I was Central Bank director and (for a short tenure) president during this critical period.

Figure 1: Since the early 80s Brazil was plagued by chronic inflation, with five failed stabilization attempts before the Real Plan of 1994

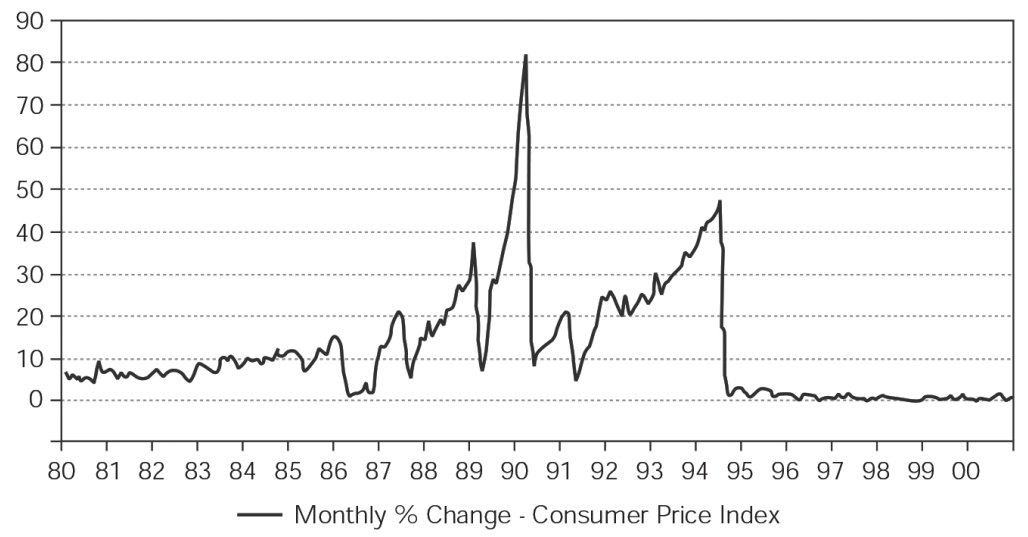

\footnotetext{
${ }^{3}$ The first of the so-called heterodox stabilization programs was the Cruzado Plan of March 1986, which managed to keep the monthly rate of inflation below $3 \%$ for seven months using a quite general freeze on prices and wages. The following attempts were far less effective. The Bresser Plan of July 1987 lasted only three months and had a minimum inflation rate of around 5\%. The Summer Plan of March 1989 lasted only two months and had a minimum inflation rate close to $7 \%$. The minimum inflation rate for the First Collor Plan of March 1990 was close to $8 \%$ in spite of a general freeze of savings accounts. The Second Collor Plan of April 1991 had better results than the first, lasting for two months with a minimum inflation rate around $5 \%$.
} 


\section{EXCHANGE RATE POLICY BEFORE THE CRISIS}

To understand the Brazilian crisis of 1997-99 one must start by looking at how exchange rate policy evolved over time in Brazil. Quite sophisticated indexation techniques were developed during a long coexistence with high inflation and the exchange rate was no exception (Simonsen 1983, Fishlow 1974). At short intervals the Central Bank announced its buying and selling rate, trying to mirror the evolution of some price index (often the industrial wholesale price index adjusted for external inflation). By early 1994, the exchange rate was on a daily crawl.

This ended in July 1994 with the Real Plan, which had de-indexation of the economy as a major goal. There was a monetary reform, changing all monetary values denominated in the old currency, the Cruzeiro, into the new currency, the Real (R\$), at a rate equivalent to one US dollar per Real. But there was no official announcement on exchange rate policy at the onset of the Plan. The Central Bank just stayed away from the foreign currency market, introducing a de facto floating but with no explicit commitments.

Monetary policy was tight. The overnight SELIC interest rate (similar to the FED funds rate), which was around $53 \% \mathrm{mr}$ (monthly rate, or the equivalent of $16354 \%$ annual rate) in the days immediately before the onset of the Real Plan, dropped to $8.7 \% \mathrm{mr}$ in the first workings days after it, and down to $4.6 \% \mathrm{mr}$ by the end of July 1994 . It stayed close to $4 \% \mathrm{mr}$ for the next twelve months. CPI inflation also dropped from $47 \% \mathrm{mr}$ in June, just before the plan, to $6.8 \% \mathrm{mr}$ in July and to an average of around $2 \% \mathrm{mr}$ for the next twelve months. Hence, the real interest rate in the money market was around $26 \%$ annual rate in this period, a very high level. Since the SELIC rate is the base rate for whole interest rate structure, there can be no doubt that monetary policy was very tight at the beginning of the Real Plan.

On the $4^{\text {th }}$ of July, the first working day after the Plan, the dollar (selling) rate closed at $\mathrm{R} \$ 0.94$. This somewhat surprising opening-day quote was, to a large extent, a consequence of the fact that a majority of banks were long in Reais, in order to hedge against any preemptive devaluation at day zero of the Plan. Hence they now had dollars to sell that the Central Bank was no longer willing to buy. In the following days, weeks and months the exchange rate went on appreciating, under the pressure of tight monetary policy and improving expectations on the success of the stabilization plan. It reached its lowest point in middle October, when it fell to R \$0.829, and stayed under R\$0.85 until the end of February of 1995.

The Central Bank did not intervene in the foreign currency market as appreciation went on. It is clear that the policy-making group at the time ${ }^{4}$ was quite happy with appreciation, as it would put additional downward pressure on prices,

\footnotetext{
${ }^{4}$ The core policy-making group at the time had four members: Pedro Malan, the Central Bank president, Gustavo Franco, its director for international affairs, Persio Arida, the head of the National Development Bank, and Edmar Bacha, advisor to the Ministry of Finance.
} 
increasing the chances of favorable inflation results in the crucial initial months of the program, when expectations tend to be volatile. There was some concern inside the group on how far appreciation should go, but not strong enough to motivate a policy change. The Central Bank would have to announce a band or a peg if it decided to intervene to avoid further appreciation, and that would reveal what exchange rate regime policy makers had in mind for the future. And, surprisingly enough, they seemed willing to hide this as long as possible. As Gustavo Franco stated recently, they wanted to "preserve degrees of freedom to face unforeseen developments as the program unfolded" (Franco 2000, p.28). ${ }^{5}$

Another consideration was that the Real Plan had set rather tight quarterly targets for the monetary base - a risky business in an environment of rapidly shifting money demand curves due to the stabilization program. Soon it was clear that even the first target, for the end of September, would not be met. It seems that policy makers feared that by buying reserves in order to avoid further appreciation, the Central Bank would put additional pressure on the monetary base. They missed the point that this would be true only if the exchange rate intervention were not sterilized by public debt. In other words, buying reserves with money raised by issuing new public debt would have no impact on the monetary base.

As a matter of fact, though the Central Bank was not buying dollars at the market from the private sector, it was selling dollars from its reserves to the $\mathrm{Na}$ tional Treasury by means of "direct" sales bypassing the foreign exchange market. This way it reduced the total demand for dollars, as the Treasury did not have to come to the market to buy the foreign currency it needed to cover the payments of interest and principal on its external debt. ${ }^{6}$ Hence the appreciation was not a clearcut result from market clearing, reflecting the relative strengths of supply and demand forces. The fact that the reserves were actually going down, shows that the Central Bank was de facto intervening, but in the direction of appreciation. This was a dirty float and the appreciation was to a large extent an artificial product of government policy

As could be expected, the appreciation of the Real was very helpful in knocking down inflation, but the huge overvaluation that resulted deteriorated the external accounts swiftly. Whether this was an important policy mistake or just irrelevant is a controversial issue that will be avoid here.

\footnotetext{
${ }^{5}$ It is important to understand that there was a sort of feudal organization in economic policy-making at the time, with exchange rate decisions being under almost exclusive control of the director for international affairs of the Central Bank, who consulted with the president of the Bank only occasionally. Hence, any psychological interpretation of this apparent commitment phobia should not be generalized to all the members of the core policy-making group.

${ }^{6}$ These direct sales were motivated by the fact that the foreign currency needs of the National Treasury were heavily concentrated on the months of April and October. Since all international reserves had to be held at the Central Bank, the Treasury was not allowed to build a foreign currency position in a gradual way. It had to come to the market only at the time of its payments and it was feared that speculators, knowing that, would then artificially create adverse market conditions.
} 
The Central Bank did intervene a couple of times in late October, when the exchange rate reached around $\mathrm{R} \$ 0.83$, so at that point one could think that this was the floor of an informal band with ceiling at $\mathrm{R} \$ 1.00$. But soon growing uncertainties over Mexico put upward pressure on the rate and the Central Bank sold reserves at $\mathrm{R} \$ 0.86$, effectively defining a new ceiling. According to Franco this "was meant to prevent depreciation which could at that time have endangered stabilization" (Franco 2000, p.32). Apparently policy makers were afraid that an exchange rate jump from $\mathrm{R} \$ 0.83$ to $\mathrm{R} \$ 1.00$, that is, a $20 \%$ devaluation, would produce a spike in monthly inflation numbers disturbing expectations. At this point it is already obvious that the lack of a well-thought exchange rate regime at the onset of the stabilization had produced a trap. Brazil had de facto moved from an initial free float to a very narrow horizontal band at an obviously appreciated rate.

When a new administration came to power in January 1995 and Fernando Henrique Cardoso, the finance minister that started the Real Plan, was upgraded to President, a couple of new economists were recruited to the core policy-making group and a fierce dispute began on how exchange rate policy should evolve. ${ }^{7}$ The Mexican situation had developed into a full-blown crisis that could end in a default and it obviously increased the Brazil risk in international markets. Our external accounts were already deteriorating sharply, with the trade balance moving from a surplus of US\$ 1.2 billions in July to a deficit of US\$ 0.8 billion in December 1994. Actually, the annual trade balance shifted from a surplus of US\$ 10.4 billions in 1994 to a deficit of US\$ 3.1 billions in 1995. Given the new, uncertain and dangerous, external environment it was undeniable that something had to be done with the exchange rate.

There were two positions in the decision making group. Franco was championing a gradual approach, by which the informal 0.83-0.86 band would slide up to a new wider and officially announced 0.86-0.92 band within two months. After that, the band would be redefined every ten working days, in such a way that the center of each new band would be given by the moving average of the exchange rate for the previous ten days. But the Central Bank would be free to intervene inside the band and its center would be a sort of target rate. Franco argued that this regime would be similar to the European Exchange Rate Mechanism (the so-called "European Snake"). He claimed this could be "a regime for the rest of our lives", and with many advantages. Its establishment would not show a "hasty decision" and would make it clear to everyone that Government saw the external accounts as a medium term problem that did not demand any "shock treatment". It would not be seen as the confession of an error in the exchange rate policy of the previous months or as surrender to injured political interests. And it would be a natural evolution of the

\footnotetext{
7 The main additions were myself, as economic policy director of the Central Bank, José Roberto Mendonça de Barros as chief economic adviser to the minister of Finance, and José Serra as minister of Budget and Planning. There was also a reshuffling of the original group. Persio Arida became Central Bank President, Edmar Bacha became head of the National Development Bank and Pedro Malan became minister of Finance.
} 
existing informal regime, avoiding any break of confidence in the relationship of the Central Bank with the market. Overall the emphasis was on defining a new formal exchange rate regime that would preserve a large degree of freedom to policy makers, giving a minimum amount of information to the market.

Most of the others, myself included, favored the immediate announcement of a classic horizontal band, with 0.92-1.00 limits and no Central Bank intervention within the band. We argued that the devaluation produced by this move, of at least $7 \%$ if the rate jumped to the floor of the new band, at a moment when our external front was not under attack, would show to investors that Government intended to keep some flexibility in its exchange rate policy, minimizing the risk of a future Mexican-type crisis. Franco's idea of a moving average band — somewhat similar to what later in this paper will be called an "endogenous diagonal band" — was welcome for the flexibility it would bring but there were doubts on how it would work in practice. I myself thought that an announced diagonal band, as used by Israel, would be preferable, but at the time the group was dominated by the fear of introducing anything that could even remotely resemble a new explicit indexation reference. This is easy to understand, as the elimination of indexation rules from Brazil's legal infrastructure was still very much a work in progress, and would yet require a presidential decree in July 1999 (a Provisional Measure). ${ }^{8}$ But the supporters of the classic band solution made it clear that soon, certainly no later than early 1996, another shift of the band floor to $\mathrm{R} \$ 1.00$ should be contemplated.

The internal dispute lasted for almost two months. At the end a sort of compromise solution was reached in which Franco was the clear winner, making very few concessions as his opponents became increasingly uneasy with the stalemate and the consequent lack of action. My mumblings at the time that it would not work were deafened by the "political imperative" of immediate action. On Friday March $6^{\text {th }}$, a formal 0.86-0.90 band was announced, but with the Central Bank free to intervene inside the band as it pleased (BACEN Communiqué 4479). It was also announced that a new $0.86-0.98$ band would go into effect by May $2^{\text {nd }}$. This implied an awkward trapezoidal band, in which the floor would remain fixed and the ceiling would move diagonally. But the path on the ceiling would produce a $67 \%$ annual return on dollar assets, while the money market SELIC interest rate was at around $47 \%$. The possibility of arbitrage was obvious: this pre-announced band was begging to be attacked. As it often happens, this political compromise type of solution for a difficult economic policy problem was not an example of prudence and good planning.

The attack came on Tuesday March $9^{\text {th }}$, when the Central Bank had to intervene more than a dozen times to keep the exchange rate close to $\mathrm{R} \$ 0.88$, the

\footnotetext{
${ }^{8}$ In Brazil, these so called Provisional Measures went into effect as soon as enacted by the President, but they had to be approved by Congress in 30 days. If, however, they were not voted in 30 days, Government could enact a new Provisional Measure with the same content, therefore keeping it in force until rejected by Congress.
} 
middle of the new band, losing almost 4 billion dollars of reserves (some $11 \%$ of the available stock). This middle rate was thought to be the appropriate policy target by the rather independent External Affairs Director, who managed the exchange rate desk of the Central Bank, given its new "European band" concept. ${ }^{9}$

Surrender was acknowledged on the following day by the announcement of a classic horizontal band, with the implicit commitment to intervene only on its limits, 0.88-0.93 (BACEN Communiqué 4492). So in the end Franco's opponents in the policy making group had won, but with a smaller devaluation than was aimed in their initial proposal of a 0.92-1.00 band. On the same day, the SELIC interest rate was moved up to around $65 \%$ annual rate, in order to show that monetary policy would punish any attack on its international reserves. Given the malaise produced by the clumsy exchange rate operation and the ongoing Mexican crisis, the loosening of monetary policy in the following months would be a gradual, painful process.

Figure 2: After the 1995 exchange rate imbroglio, the fall of the interest rate was a rather gradual process

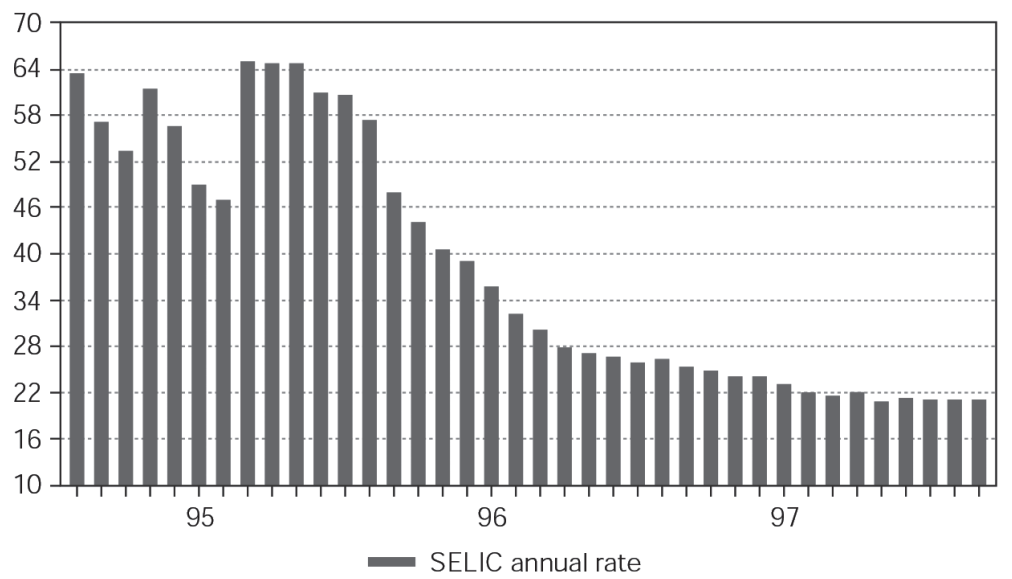

The March 1995 exchange market turbulence in Brazil was not really a Mexican contagion. It was entirely of domestic origin, the result of a badly organized decision process under feeble leadership. But it had some very negative consequences for economic policy. Persio Arida, the brilliant Central Bank President, resigned few weeks later, after being unjustly accused of indecorous behavior by the press ${ }^{10}$ and going through a couple of long inquiry sessions in Congress. And

\footnotetext{
${ }^{9}$ The Central Bank, in a desperate attempt to show that it was serious about its innovative European band concept, sold limited amounts of forward dollars due May $2^{\text {nd }}$ at 0.92 . This would be the center of the new band on that date but the market did not pay any attention.

${ }^{10} \mathrm{He}$ was accused of going to a country party given by a banker friend a few days before the exchange rate announcement!
} 
from that moment on, discussions on exchange rate policy became taboo in the policy making group, to be avoided whenever possible.

The exchange rate band worked well, with the expected smooth padding, until June $22^{\text {nd }}$. On that day a new 0.91-0.99 band was announced and, far more important, with it came a new mechanism of intervention in the foreign exchange market. It was the "spread-auction", by which the Central Bank could at any time force all sixty dealers to present bid and ask offers. It defined the minimum amount and the maximum spread for the offers, and was free to trade with any dealer either as seller or buyer. Hence, if the market had inconsistent non-overlapping spreads, the Central Bank could make money by arbitrage, buying from one dealer and selling to another.

The spread auction was introduced by means of a directive of the foreign currency desk of the Central Bank (BACEN, Communiqué 4637) and, in the scant discussion of it in the policy making group (remember, this was now a taboo matter), Franco claimed it was just a minor technical improvement in operating procedures that would increase his ability to fight market speculation. But since he operated the new auction mechanism with a very small maximum spread, of around $0,5 \%$, it really amounted to pegging the exchange rate.

The market soon started to refer to this $0.5 \%$ spread as the "inner-band" (or "mini-band"), understanding that the larger 0.91-0.99 band had became irrelevant. Without any real discussion, the exchange rate regime had been changed, by an apparently insignificant "operational detail”, from the classic horizontal band established on March $10^{\text {th }}$ to a straight peg (Figure 3). So in the end Franco had again won, as it became clear that his "regime for the rest of our lives" was really a fixed exchange rate with a gradual crawling. ${ }^{11}$

The speed of crawling was not officially announced. As always, Franco wanted to preserve his degrees of freedom, but soon a pattern of fixed monthly devaluation arose. The exchange rate moved about $0,6 \%$ per month, which amounted to $7,5 \%$ per annum and this came to be regarded as the informal policy rule. Since CPI inflation went down to $5.2 \%$ in 1997 and $1.6 \%$ in 1998, the crawl produced a total real devaluation of $8.7 \%$ over these two years and started to be seen as a feasible, though somewhat gradual, way out of the huge overvaluation. ${ }^{12}$

It is interesting to speculate on how things could have been different if the shortlived band experiment of March-April 1995 had been allowed to proceed. During 1996-1997 the Central Bank was most of the time buying reserves in the market, due to capital inflows and to the fact that the National Treasury was still fulfilling its reserves needs in direct, off-market, operations with the Central Bank.

\footnotetext{
${ }^{11}$ Franco (2000, p. 69) describes this as "specific technologies [...] developed to reduce volatility within the zone " (i.e., the large band) "and to allow for quiet transitions to higher zones, so that the regime, through time, could prevent further appreciation and allow for some mild devaluation".

12 In December 1996, the devaluation needed to bring the real exchange rate to the level of the end of June 1994 was around $54 \%$.
} 
Figure 3: Brazil exchange rate policy 1994-1995:

floating 0.88-0.93 band and crwling peg

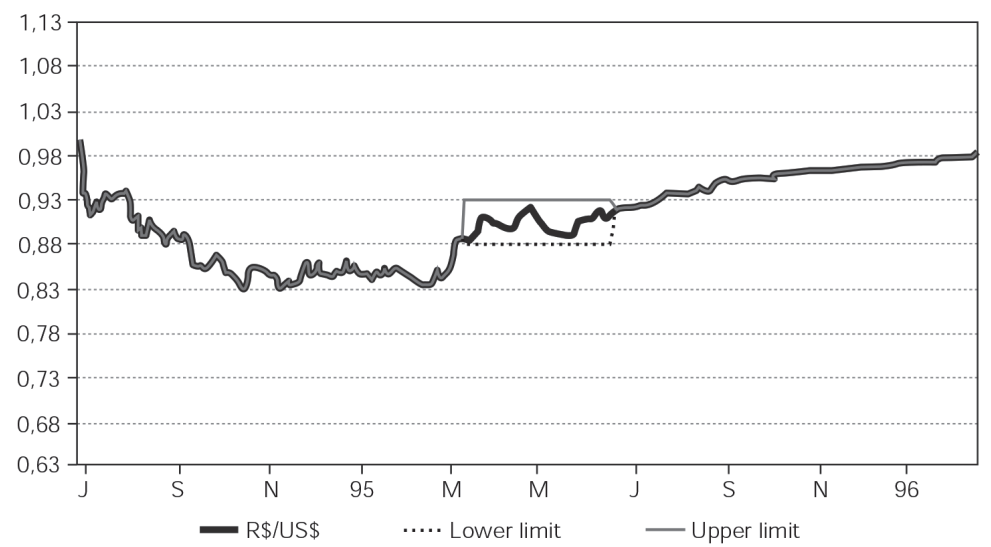

Hence, in a band regime the rate would be most of the time close to the floor. This would be the ideal context for a gradual widening of the band so as to accomplish an orderly exit to a floating rate (Eichengreen 1997). But, as a matter of fact, the notion that a floating exchange rate should be the ultimate policy goal was never consensual within the policy making group. Franco was still skeptical as late as May 2000 , in spite of the huge unequivocal success of the January 1999 devaluation. ${ }^{13}$

\section{OCTOBER 1997: PARADISE LOST}

The Asian Crisis, which started with the floating of Thai's Bath in July 1997, had at first little impact on Brazil. ${ }^{14}$ The C-bond spread over Treasury surprisingly went down, from an average of 421 points in June 1997 to 360 points in October $20^{\text {th }} 1997$. It looked as if the Brazilian crawling peg regime was safe from external contagion.

Then, on October $23^{\text {rd }}$, the Hong Kong Monetary Authority reacted to several days of pressure on the HK dollar by letting the overnight interest rate rise from $7 \%$ to around $300 \%$. The Hong Kong stock market had suffered its heaviest crash ever, losing a quarter of its value in four days. The immediate cause seemed to be the $5 \%$ devaluation of the Taiwan dollar in the previous week. Since Taiwan, a country with substantial foreign exchange reserves, was unwilling to keep up a

\footnotetext{
${ }^{13}$ Franco wrote "it is useful to inquire, in the light of the experience reviewed in this essay, whether there is a third way between the currency board and the pure float" (Franco 2000, p. 70).

${ }^{14}$ For a detailed chronology of the Asian Crisis, see Nouriel Roubini's website at http://www.stern.nyu. edu/globalmacro/AsiaChronology1.html.
} 
fixed link to the US dollar, doubts were raised about Hong Kong's commitment to its longstanding peg and markets had to go for a test.

On Monday, October 27th , global markets seemed to react to what looked like a spreading Asian Crisis, and the Dow Jones industrial average fell 554 points, or $7.18 \%$, its single-biggest point loss ever. Stock markets throughout Latin America also suffered record losses, and Brazil's IBOVESPA index fell by $15 \%$, producing a $24 \%$ drop in three days. But the C-bond spread moved only to 532 basis points (up 152 bps in two days), suggesting that there was no drastic loss of confidence on the exchange rate regime.

Then, on Tuesday, October $28^{\text {th }}$, there was a surprising development. In Brazil, many Central Bank directors (and sometimes presidents) had their families living in Rio or São Paulo, where they would spend the weekends, flying back to Brasília every week. Very often they worked Mondays and Fridays on regional offices. On that Tuesday, as I boarded the plane in Rio for the one and a half hour flight to Brasília, I noticed that Gustavo Franco, who was then the bank president, was also on the same flight. As usual we used our time to read the morning's newspapers but as the plane landed in Brazil's capital, around $10.30 \mathrm{am}$, we got the news that our foreign currency desk was well on the way to selling ten billion dollars in that single morning, about $15 \%$ of our international reserves.

At first we thought a speculative attack was on the way, but as the pressure faded away in the afternoon we could figure out what was really happening. Remember that the dollar futures market was rather deep in Brazil, being the number one source for short-term foreign currency hedge. There was also a liquid interest rates futures market (the so called CDI futures market), trading the present value of a short-term loan paying the overnight inter-bank rate (the CDI rate, a benchmark for bank's basic cost of funds). Hence, at any given moment, if the spread between future and spot exchange rate became wide enough, banks could profit by an arbitrage operation in which they would buy spot dollars, sell future dollars and buy CDI futures so as to cover for the interest rate cost of the domestic currency used to buy the spot dollars.

If banks had no clients at that moment who happened to be willing and authorized to send dollars abroad, through one of the available windows in the complex Brazilian exchange market regulations, they would have to deposit their excess dollars with the Central Bank, earning a penalty interest rate (initially a fraction of LIBOR, later on reduced to zero). This meant that the opportunity cost of foregone interest earnings on these dollars had also to be accounted for in the arbitrage calculations. It also meant that most dollars bought for this arbitrage operation never actually left the country. They were taken out of Central Bank reserves just to be deposited back in the same Central Bank.

It should be stressed that this arbitrage opportunity was only open to banks with permission to trade in the inter-bank foreign currency market. It was not open to ordinary individuals or corporations. Brazilian exchange market regulations were based on the principle that you are allowed to buy dollars only if you have a "valid" reason for it. This meant essentially that you had to be an importer of goods 
or services, a foreign investor repatriating profits or dividends, or a debtor servicing obligations due on a foreign loan. ${ }^{15}$

Our exchange rate policy was pegging the exchange rate in the spot market but we had set ourselves a limited allowance for intervention in the futures market (of around US\$ 3 billion, a small fraction of our international reserves of more than US\$ 50 billion), at the discretion of the foreign currency desk. With the Hong Kong crisis and the worldwide debacle in stock markets, demand for hedge surged in Brazil and could not be satisfied by the Central Bank within that limited allowance. Hence, the futures-spot spread widened and buying spot dollars for arbitrage became profitable. That was the reason we had lost reserves so swiftly and it taught us the important lesson that, with such a deep dollar futures market, our spot market peg had to be supported by a futures market peg if it was to be sustainable.

Of course when banks bought spot dollars to sell futures, they were increasing supply in the futures market and hence helping to stabilize its price. But this builtin stabilizer could function only as long as the Central Bank had reserves to sell in the spot market. On the other hand speculators could buy dollar futures in the Brazilian Mercantile and Futures Exchange (BM\&F) with a small initial margin deposit, which was set as low as $1.5 \%$ of the notional amount bought. In other words, a speculator needed only 15 million dollars to back a one billion dollars bet. On the other hand, if banks were to be the counterpart of this bet by means of an arbitrage operation, they would need to buy one billion dollars on the spot market, which would flow out of reserves. It was clearly very inefficient to face a speculative or hedging pressure on the futures market by supplying an unlimited amount of dollars in the spot market. To sustain the spot peg with limited amount of reserves, even in the Brazilian regime of partial capital controls, the Central Bank had to be willing to sell unlimited amounts of dollar futures.

That became our policy after the October $28^{\text {th }}$ scare. Our foreign exchange desk put in place a system to calculate on real time the arbitrage futures-spot spread as a function of the future overnight inter-bank rate (CDI) and the cost of short term borrowing lines for Brazilian banks. The policy now was to sell the amount of future dollars needed to keep the actual spread smaller than the arbitrage spread. By December $15^{\text {th }}$ the Central Bank net sold position in dollar futures amounted to $50 \%$ of international reserves and to $72 \%$ of the market!

It is possible that this extended peg policy, covering both spot and future markets, would be sufficient to sustain by itself the exchange rate regime at that time. There was no evidence of a genuine speculative attack; it looked more like a moderate increase in the demand for hedge. But the press, the general public and IMF staff soon learned about the swift loss of reserves and in their minds this was clear

\footnotetext{
${ }^{15}$ You could buy dollars to travel abroad or to pay credit card expenses or to send to a relative abroad only at to the so-called "floating rate" market, which was a sort of legalized black-market. This was also operated through banks but with no communication allowed with the main market, of which it represented some 10 percent. Trading in floating rate contracts at the futures exchange always had a small volume.
} 
evidence of a speculative attack. Market specialists who understood the role played by the futures-spot spread knew better, but they also knew that the reserve loss could put Brazil "in play" for international speculators. We obviously needed to establish a reputation of being ready to defend our exchange rate regime at any cost. Hence, on October 31 3 st $^{\text {st }}$ we increased the SELIC overnight rate from $20 \%$ per annum to almost $45 \%$.

One may wonder, from today's vantage point, whether this dramatic monetary policy tightening was indeed necessary. Theoretically we could always protect the exchange rate regime by selling unlimited amount of dollar futures. But we felt we needed to establish a reputation as an orthodox central bank. We did not want to be seen as relying exclusively on such unorthodox policies as selling futures. As a matter of fact, we never disclosed our net position in the futures market, in spite of insistent demands from the IMF. ${ }^{16}$

We also thought that a high interest rate would reduce the current account deficit, which was one of the perceived vulnerabilities in our economy. At that time, commercial banks had quite unbalanced balance sheets, owning a significant amount of fixed interest rate Government bonds, with average maturity of more than six months, which they financed mainly with short-term deposits linked to the overnight interest rate. Hence, the interest rate hike produced an important capital loss for banks, which amplified its credit contraction effect. The credit crunch depressed economic activity and GDP growth, reducing imports and improving the current account.

Of course one negative side effect of high interest rate would be an increase in the nominal public deficit, which is evaluated in Brazil by a quite broad Public Sector Borrowing Requirements (PSBR) measure. ${ }^{17}$ To deal with that, on November $10^{\text {th }}$ Government unveiled an $\$ 18$ billion (approximately 2 percent of GDP) belttightening plan designed to reassure investors it was prepared to swallow whatever bitter medicine was necessary to defend the economy against attack. The measures, which included a hike in income tax for upper brackets and a 15 percent across the board cut in federal spending, became known as the "51 Package". ${ }^{18}$

There has been a lot of controversy on whether this fiscal package was too shy or too badly implemented. Franco, for example, mentions a "serious credibility gap

\footnotetext{
16 The Central Bank operated in the futures market through Banco do Brasil, who also traded for his own account and for his clients. The actual amount traded for the Central Bank was not known even for market participants. Only in late 1998, did the IMF managed to receive official information on the Central Bank futures book.

${ }^{17}$ Brazil' s PSBR is measured by the change in the net debt position (that is, debt minus liquid financial assets) of federal government, Central Bank, social security, state and municipal governments and state enterprises.

18 This was from the fact that Government presented a long list of 51 fiscal measures, many of which of rather limited relevance and clearly aimed at making an impact on the press, combined with a television advertisement for the popular "cachaça" liquor brand " 51 ", which had the motto " 51 is always a good idea”.
} 
produced by the non-delivery of the [...] promised fiscal effort. An effort of 2 percent of GDP has been promised when PSBR was already at 6 percent. A year later, in September 1998, the PSBR was at 8.3 percent and climbing" (Franco 2000, p.57). But this is an unfair evaluation. The primary PSBR of the Federal Government (excluding interest payments) moved from a deficit of $0.27 \%$ of GDP in 1997 to a surplus of $0.57 \%$ of GDP in 1998 . Total primary PSBR, including state companies, state governments and municipalities, moved from a deficit of $0.93 \%$ of GDP in 1997 to close to zero in 1998. But this improvement was not sufficient to compensate for the increase in interest payments, which moved from 5.1\% of GDP in 1997 to $8 \%$ of GDP in 1998 , due to the interest rate hike.

It is important to consider that a temporary interest hike produces a permanent increase in public debt but only a temporary increase in nominal PSBR. Hence there is room for Government discretion on how much of the additional interest cost produced by a temporary monetary restrain is to be absorbed by the present generation, through increased taxation or reduced public expenditures, and how much will be shifted to future generations through higher public debt. Of course what is relevant for the evaluation of fiscal sustainability is the long run position of the primary surplus (which excludes interest payments) and the long run position of the interest rate. From that point of view the now standard evaluation of the 51 Package as a complete failure, with negative credibility repercussions later on, may be rather unfair, though perhaps adequately representing the dominant mood in financial markets by late 1998 .

Another side effect of the interest rate hike was a spectacular increase in international reserves, which moved from US\$ 52 billion in November 1997 to US\$ 74.6 billion in April 1998. This produced a lot of optimism inside government. Brazil's tough orthodox Central Bank had won the battle against international speculators! Our reputation was never so high with international organizations and the international financial community.

That seemed an adequate moment to move towards a gradual increase in exchange rate flexibility (Eichengreen, 1997). Once again the decision making team was stuck in internal debate, with Mendonça de Barros and myself pressing for changes, Franco strongly opposing any change ("why change if we have won" was his preferred motto) and finance minister Pedro Malan unable to decide. Finally by the end of April we did manage to introduce a very timid change in the exchange rate regime, with the announcement that the inner-band spread, which had been fixed at around $0.5 \%$ since 1995 , would widen gradually overtime, at a rate of about one percentage point per year.

It should be remembered that, since the exchange rate was allowed to float within the inner-band, if its spread was going to widen over time, this would mean increasing exchange rate flexibility. But the movement was too gradual to make much of a difference in any relevant policy horizon. At this speed it would take more than five years to reach the $5.6 \%$ band spread that we had for a while in 1995 (with the R \$0.88-0.93 horizontal band and before the introduction of the innerband). Our last opportunity to introduce significant changes in the exchange rate 
regime under no-stress conditions had just been lost. The following storm would force us to fix it under pressure.

\section{FALL 1998: THE RUSSIAN CONTAGION}

The first semester of 1998 was a relatively tranquil period for international finance. The successful defenses put up by Hong Kong and Brazil at the end of 1997 seemed to have stopped the sequence of contagion crises started by the Thai devaluation of July 1997. It is true that the Russian economy still seemed in bad shape, with a lack of strong political leadership, but now they had IMF support and seemed to be straightening things up.

In the beginning of the second semester, the crisis came back with added virulence. On July $28^{\text {th }}$ the Wall Street Journal had a headline on possible huge losses by Long Term Capital Management (LTCM), the hedge-fund created by legendary trader John Meriwether together with two Nobel Prize financial economists and an ex-vice chairman of the FED. ${ }^{19}$ This was the first indication that the financial crisis could be spreading beyond emerging markets, and forced a reevaluation of risks on high yield investments everywhere.

On Thursday, August $13^{\text {th }}$, the Hong Kong Hang Seng stock market index fell by $8 \%$, in what seemed to be a speculative attack through the stock market, a rather unconventional route. This forced the Hong Kong Monetary Authority (HKMA) to announce, on the following day, the unprecedented policy of buying stocks directly to avoid further declines in the stock market index. ${ }^{20}$ Of course,

\footnotetext{
${ }^{19}$ For details on LTCM see Lowenstein (2000).

${ }^{20}$ The Hong Kong stock market attack according to Joseph Yam, Chief Executive of the HKMA, was a "double play" by which speculators shorted the currency to squeeze up interest rates thereby profiting from short positions in the stock market as it tumbled. Yam (1988) gives some colorful details: "They [the speculators] introduced a form of double play aimed at playing off the currency board system against the stock and futures markets. First, to avoid being squeezed by high interest rates, they prefunded themselves in Hong Kong dollars in the debt market, swapping US dollars for Hong Kong dollars with multilateral institutions that have raised Hong Kong dollars through the issue of debt. At the same time, they accumulated large short positions in the stock index futures market. They then sought to engineer extreme conditions in the money market by dumping huge amounts of Hong Kong dollars. This sell-off was intended to cause a sharp interest rate hike, which in turn would have sent the stock market plummeting. The collapse of the stock market would have enabled them to reap a handsome profit from the futures contracts they had taken out. A few figures will help give some idea of the scale of this attack and the vulnerability of Hong Kong's markets at the time. We estimate that the hedge funds involved had amassed in excess of $\mathrm{HK} \$ 30$ billion in currency borrowings, at an interest cost of around $\mathrm{HK} \$ 4$ million a day. They also held an estimated 80,000 short contracts, which translated into the following calculation: for every fall of 1,000 points in the Hang Seng index they stood to make a profit of $\mathrm{HK} \$ 4$ billion. If they could have engineered that fall within 1,000 days they would have broken even. If they could have achieved it within 100 days they would have netted HK\$3.6 billion. All they had to do was to wait for the best moment to dump their Hong Kong dollars, to drive up interest rates and send a shock wave through the stock market. August was an opportune time: turnover in the stock market had shrunk to about a third of its normal level; there was bad news as the Government
} 
only Hong Kong's very special fiscal position could give this defensive policy a fair chance of success. ${ }^{21}$ Basically the HKMA was learning a variant of the same lesson Brazil's Central Bank had learned in 1997: a fixed exchange rate will not survive if there is a free derivative market of sufficient liquidity in a somehow connected financial asset.

On these days Franco told me of a call he had just received from a chief executive in the emerging markets department of a major international bank, warning him that the Russians were on the brink of default. He had told him that the move had the disguised blessing of the IMF and it would be disaster for Brazil. Franco told me that, after talking to a leading IMF official, he was now sure they were really implicated.

Few days later, on Monday August 17th , we had the devaluation of the rouble and the Russian default. This time the emerging bonds market really collapsed. The Brazil EMBI spread moved from 671 basis points (bps) on August $6^{\text {th }}$ to 834 bps on August $18^{\text {th }}$, and to 1524 bps on August $27^{\text {th }}$. It seemed that our worst scenario had just come true. We were now facing a huge international financial crisis, in which Brazil would inevitably be seen as the next target, and this was happening just one month before the first round of a two rounds presidential election.

After the 1997 interest rate hike I had attended an informal private meeting at the BIS in Basle with G7 central bank governors to discuss what was going on in Brazil. Sir Edward George, the UK central banker, asked me point-blank: "what would Brazil do if there is another run on its international reserves?" My answer was firm: "we do it again!" But in my inner-self I was not so sure. Would there be support in Government for another round of defensive monetary tightening plus fiscal adjustment in an election year? In our internal discussions, Mendonça de Barros had been prophesizing that there would be another test - as he put it - to our exchange rate regime before the election, but he never could really explain why he thought so. Now he had been proved right and the challenge was how to raise the interest rate again and at this stage of the political cycle.

announced that firstquarter GDP growth had been negative; and rumors were flying around predicting the devaluation of the Renminbi and the severing of the link between the Hong Kong dollar and the US dollar. We acted swiftly to defeat the manipulators at their own game with a series of measures that threw them off their guard, drove them out of the market, and raised the defences against future attacks. First, drawing on the official reserves, we went into the stock and futures markets. In the second half of August we accumulated US $\$ 15$ billion worth of shares: I am happy to say they are now worth US\$19 billion, but our aim was not to make money; it was simply to deter manipulation by making sure that it did not pay off. That objective was achieved. The manipulators were forced to close out their short positions, in many cases with heavy losses. And we followed through with a package of technical measures to strengthen our currency board arrangement to make our money market less susceptible to manipulation."

${ }^{21}$ The Hong Kong Government was the owner of all the land and received stable revenues from land leases. It had been running a fiscal surplus averaging $2 \%$ of GDP and had no public debt. See HKMA (1995, p.63). 
Figure 4: In october 97 Central Bank's reserves losses resulted

mostly from arbitrage by brazilian banks; almost no

net US \$ outflow different from large outflows $2^{\text {nd }}$ semester 98

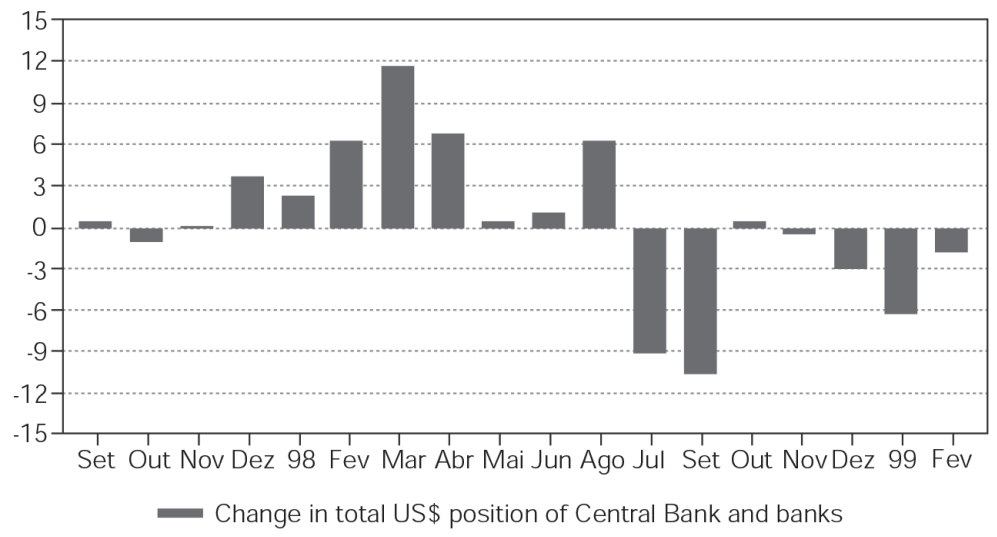

As a matter of fact the timing of the crisis was not as bad as it would have been if it had happened some months before. We were just at one month from the first round of the presidential election (to be held on October, $4^{\text {th }}$ ) and polls were showing that President Cardoso would be reelected in the first round. A gradual monetary tightening over the month of September would not produce negative side effects fast enough to change the political odds. It would have been a much more difficult decision if it had to be taken a couple of months earlier, because then it would be seen as a real political risk.

It is useful at this point to explain how monetary policy operated at this time, in a setup inspired by the Bundesbank tradition..$^{22}$ There was a rediscount window where banks could finance federal debt holdings up to a certain quota (linked to their net-worth) at the so-called TBC rate. This was similar to the discount rate in the German system and under normal conditions played the role of an interest rate floor. There was also an interest rate ceiling, defined by the TBAN rate (similar to the German Lombard rate), at which banks could get unlimited amounts of finance for the federal debt holdings. In principle the SELIC overnight rate could float freely inside this interest rate band in response to liquidity changes and the Central Bank would not peg it directly through open-market operations. But by playing with the rediscount quotas and the amount of federal debt (including central bank debt) auctioned each week, it could put the SELIC overnight rate close to TBC floor or to the TBAN ceiling. Most of the time the system operated with the SELIC rate close to the TBC. The TBC and TBAN rates could only be changed at meetings of the Monetary Policy Committee (COPOM), which met regularly every five weeks or so and decided by majority vote of the Central Bank directors. The COPOM

\footnotetext{
${ }^{22}$ See Deutsche Bundesbank (1995). This setup was abandoned in early 1999 by request from the IMF.
} 
decision was announced by a short press release in the same day, and minutes of the meeting were published with a two months lag.

After the Russian default, interest rate was increased in four stages. First, the COPOM meeting of September $2^{\text {nd }}$ increased the TBAN ceiling by 4 percentage points, from $25.75 \%$ to $29.75 \%$ annual rate, while keeping the SELIC rate close to the $19 \%$ ТВC rate. The idea was to give an initial indication that interest rate could be moved up in the near future, thereby immediately affecting longer term interest rates while keeping the overnight rate constant. In other words, the Central Bank hoped to influence the term structure of interest rates by announcing a higher overnight interest rate ceiling.

In a second stage, on September $4^{\text {th }}$, the rediscount window at the $19 \%$ TBC rate was closed, making the SELIC rate jump to the TBAN ceiling of $29.75 \%$. The TBC window was to remain closed until December $16^{\text {th }}$.

On September $10^{\text {th }}$, the third stage came in an unusual extraordinary COPOM meeting ${ }^{23}$ that increased the TBAN rate to $49.75 \%$. The COPOM also took the unusual step of planning daily interventions through open market operations that, after an initial 10 percentage points jump (hence to $39.75 \%$ ), would gradually move the SELIC rate up until the end of the month. Hence the fourth stage was this gradual crawling of the SELIC rate up to $42.75 \%$ on November $4^{\text {th }}$, with an additional increase of 3 percentage points.

The process of increasing interest rates was cumbersome and gradual, as opposed to the single swift movement of 1997 . Monetary policy had to take into account political realities and the psychological cost of going back to high interest rates - not to mention its fiscal consequences.

As a matter of fact, the Central Bank never thought that $42.75 \%$ was to be a new permanent plateau for the interest rate - a point that seems to have been misunderstood by the IMF staff. Rather it was seen as a temporary peak — needed to show our monetary policy resolve in fighting attacks on the exchange rate peg. Indeed, after the COPOM meeting of November11th, which reduced the TBAN rate to $42.25 \%$, open market operations were again used to produce an initial jump to $39.5 \%$ in the SELIC rate, followed by a rather gradual decline down to $29 \%$ in December 17 th, when the rate stabilized. The average SELIC rate was $34.5 \%$ in September, $41.5 \%$ in October, $38.7 \%$ in November and $31.2 \%$ in December. These rates were similar to those used in the successful defense of the exchange rate regime at the end of 1997. Real interest rates were again close to $30 \%$ annual rate. On the face of these numbers it sounds absurd that the IMF could complain of a weak monetary policy in discussions with the Brazilian Government in early 1999. ${ }^{24}$

\footnotetext{
${ }^{23}$ This was the only case of an extraordinary meeting of the COPOM since it was created in June 1996, which reminds us of the dramatic nature of events. This meeting was also important for a rather unusual discussion on exchange rate policy, which we will report bellow.

${ }^{24}$ In January 1999 the IMF needed an explanation for the "failure" of the Brazilian program to sustain the
} 
Figure 5: Real interest rates in the end of 1998 reached

all time records, surpassing $35 \%$ in annual rates

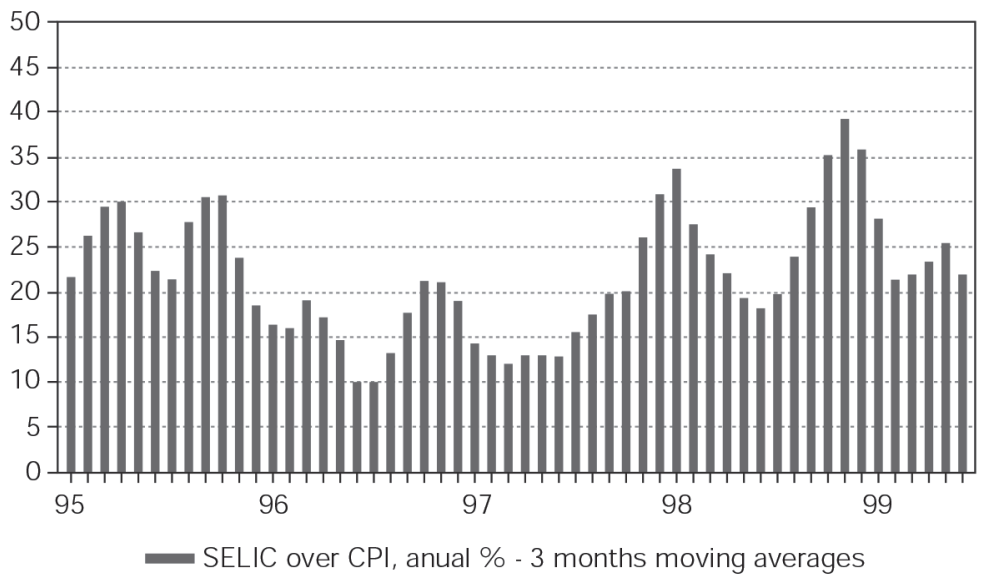

Why did this combination of high interest rate and an IMF program failed to stop the reserves slide? As pointed by Obstfeld and Rogoff (1995), fighting a speculative attack is a complex game of strategy, in which credibility is a key issue. Markets know that central banks will not cling to a peg indefinitely without consideration for the disruptive side effects resulting from the defense. The time dimension is crucial: speculators must be quickly convinced that the exchange rate regime will not be changed in the foreseeable future, so that interest rates can fall back to normal levels. Lack of credibility will make the task practically impossible.

In the last quarter of 1998, Brazilian government was generating very disturbing public signs of lack of resolve and ambiguous goals. Though it wanted an IMF program, with its inevitable (and often unreasonable) austerity requirements, it also wanted to put the economy quickly back on a growth path. President Cardoso announced the creation of a new Ministry of Production for his second term, starting in January 1999, which would look for the needs of the "production economy", so heavily hit by Central Bank policies. One of his closest associates, widely seen as the most probable name for the new job, was openly critical of high interest rates and asked for a new, more microeconomic oriented, approach to economic policy.

The São Paulo Industrial Federation (FIESP), which represents industrial interests from the wealthiest region of the country, supported the new ministry concept and openly asked for an exchange rate correction. The press delighted on a supposed battle between monetarists and "desenvolvimentistas" (which means, development supporters) inside government. Some influential ministers close to the President were seen as desenvolvimentistas. Minister Malan, the ultimate guarantor of the IMF deal, 
Figure 6: After september 1998 high interest rates and an IMF program were not enough to avoid persistent reserves losses

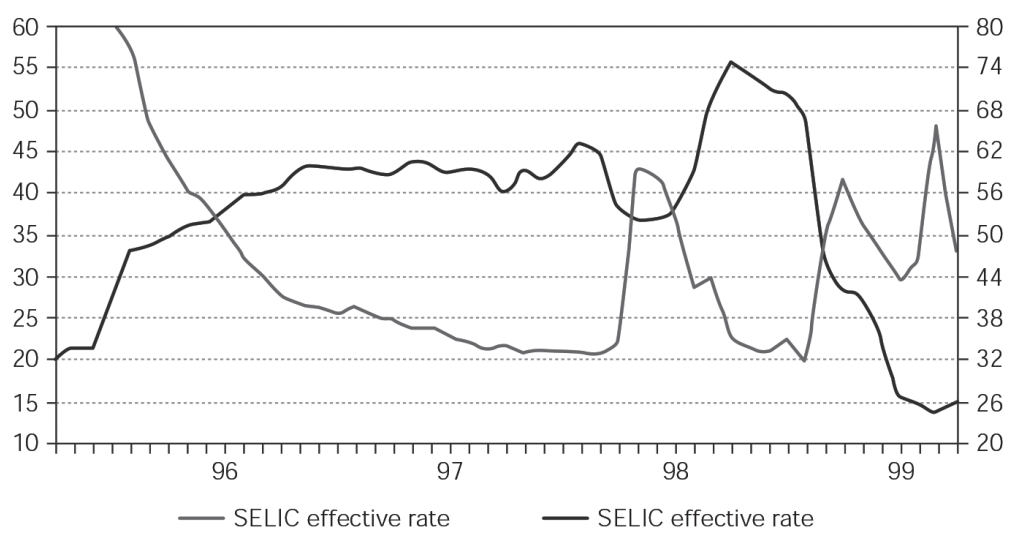

was seen as weak, tired and prone to be replaced in the second presidential mandate..$^{25}$ With all these disruptive elements abounding in the press, it is no wonder that markets were only willing to bet against the exchange rate policy.

In retrospect it is clear the IMF program was a mistake: its timing was wrong and it avoided the crucial exchange rate issue. It was announced as an international initiative to strengthen the Government effort to defend an exchange rate regime that most economists and markets players already thought doomed. ${ }^{26}$ Since the program goal was to support the peg, changing the regime, as happened in January 1999, had to look like a betrayal — a breach of contract, as Mr. Candessus told us later. Perhaps this uncomfortable feeling in Washington could have been avoided if we had cared to submit the initial decision to increase exchange rate flexibility to long discussions with the IMF and US Treasury staff. But this was out

\footnotetext{
${ }^{25}$ Of course, Malan knew it better. Being the preferential interlocutor with the IMF, an old close friend to Stanley Fischer and widely seen as an able international financial diplomat, became unbeatable political trumps under a Fund program. The Minister quickly consolidated his position and was soon able to dislodge all his (actual and imaginary) enemies from Government.

${ }^{26}$ During the program discussions I got the impression that IMF people wanted to include G7 money in the package not just to reach a large total amount of money but also to commit some of the strongest critics of the exchange rate peg. Almost all the time of a long, all day meeting with Stanley Fischer and a couple of high level Brazilian officials in Rio de Janeiro (far from the Brasilia press), was spent on the demand by European governments that Brazil's Central Bank should force foreign banks to accept a voluntary participation in the program by committing to keep their trade lines levels. Exchange rate and fiscal issues were barely touched on. Brazilians were puzzled by the idea of "forcing a voluntary participation": how do you do that without giving bankers additional incentive to take their money out? We thought it was utter nonsense, as we were not planning to default. We could see however that the IMF craved for G7 participation and hence had to pay some lip service to some of their most awkward demands. We were told that European governments needed to be reassured that this program would not be a replay of their Russian experience, in which public money inflows had been used to finance private money outflows.
} 
of question, as only half a dozen people were participating in the discussion in Brazil, and the group was very much concerned that any leak could seriously deteriorate an already difficult position.

\section{JANUARY 1999: TOTO, WE ARE NOT IN KANSAS ANYMORE!}

In order to understand what happened in January 1999, we must go back to the extraordinary COPOM meeting on September 10th,1998. This was a rather dramatic meeting. The SELIC rate had been increased to the TBAN ceiling of $29.75 \%$ on September $4^{\text {th }}$ but financial markets were giving no signs of restored confidence. It seemed to me that we had to put the interest rate back to around 40\%, as we did in September 1997 and I asked Franco to convene an extraordinary meeting in order to get that.

The meeting was tense and my first impression was that some of the participants were close to panic. I put forward the proposal of another interest rate increase but Franco soon embarked into a long lecture on the economic history of the thirties, explaining the gold standard experience and arguing that history teaches that abnormal external conditions require unorthodox policy responses. He pointed to Carlos Diaz Alejandro (1985) good-humored use of Dorothy's phrase, from The Wizard of $\mathrm{O} z$, to resume the current situation: "Toto, we are not in Kansas anymore". He explained that, given that external financing for emerging economies had collapsed, it was time to think on less orthodox solutions. $\mathrm{He}$ proposed the introduction of limited capital controls, restricted to the so-called floating rate market, as a necessary complement to any additional interest rate hike.

There was strong support from some participants. Somebody claimed that increasing the interest rate at that moment would be like "firing at our own foot": painful and useless. I replied that I would rather shoot my foot than my head. For me any movement towards capital controls would have very negative impact on expectations, leading to disaster. It followed a fierce debate before it became clear that a majority of participants were opposed to capital controls. The position of some of the more experienced directors, who had had long careers as Central Bank employees, was fundamental for settling the issue. They argued that under present conditions "limited" capital controls were not feasible. If we wanted to play with this sort of instrument, experience taught that we should go straight to full capital controls in the old Brazilian tradition.

At the end of the meeting we had decided to increase the SELIC rate to $39.75 \%$ and to postpone any discussion of capital controls. As a matter of fact it had been quite improper to discuss this sort of subject in a COPOM meeting, which is supposed to deliberate only on interest rate policy. This is a large meeting, attended by many staff people, and it worried me that it could leak to markets that capital 
controls were being seriously discussed in the Central Bank. But most of all, what astonished me was that capital controls were indeed seen as a policy alternative by leading policy makers.

The September $10^{\text {th }}$ COPOM meeting had a profound impact on my thinking on exchange rate policy. I understood now that the threat of Brazil going back to capital controls, if the crisis did not go away, was very high. This would lead to external debt restructuring and put us back into the same bad-debtor position we had experienced for the previous twenty years. It meant, among other things, no more international credit cards and no more foreign direct investment. Once more Brazil would show to the international financial community that it is not a worldclass player that knows how to honor its contracts.

I made my mind that our exchange rate regime had to be changed as soon as possible, moving towards much larger flexibility even at the risk of being forced to jump into free-floating. Above all it was fundamental to avoid capital controls and external default. For me the invitation to assume the presidency of the Central Bank meant that I would have considerable control over this decision. President Cardoso gave a strong hint that he wanted a change in the exchange rate regime. It would make no sense, he said, just to change the head of the Central Bank; we also needed a change in exchange rate policy.

It was in this frame of mind that I developed the idea of the diagonal endogenous exchange rate band, which is explained in detail in the Appendix A. It was called diagonal because both its floor and ceiling increased over time. The distance between the two limits also increased over time, aiming at a smooth gradual transition into free floating. But the real innovation was that the movement of the band was endogenous, determined by the position of the actual exchange rate relative to the band limits. When the actual rate came close to the ceiling, the speed of the upward movement of the band would be reduced, making it possible to defend it with a smaller increase in the interest rate. On the other hand, when the actual rate came close to the floor, the speed of upward movement would be maximized, since in this position there would be no need to defend the band by increasing the interest rate. On the contrary, in this last case, the increase in the speed of band movement would mean a higher minimum predictable rate of devaluation in the long run, helping to reduce the inflow of capital.

President Cardoso and some of his close associates were very optimistic with the scheme, mostly because it seemed to allow the desired change in exchange rate policy without the need of any interest rate increase. I was not so sure. I wondered if it was not too late for any solution short of floating. Was it not a good idea with the wrong timing? It certainly should have been implemented much earlier.

But from my point of view this was a clear win-win situation. The diagonal endogenous band was an obvious improvement over the existing crawling peg regime, with its almost infinitesimal mini-band. It introduced a diagonal band of plus/ minus $4.8 \%$ around the center, which would widen by about one percentage point 
per year, reaching around plus/minus $8.5 \%$ in three years time. If it could not be sustained, we would float, and this was clearly communicated to President Cardoso. Default was out of the question and now I had almost full control over this risk.

For other people the situation looked much less comfortable. Minister Malan was not happy with the regime change. He was dead afraid of the consequences and made me promise the Central Bank would intervene inside the new band, at around R\$ 1.27 per US\$, limiting the initial devaluation to no more than $5 \%$. By the end of the first day of the new regime he complained I had not fulfilled my promise, as the market was operating at the new ceiling of $\mathrm{R} \$ 1.32$. I just told him the R \$ 1.27 would be our target rate for the end of the month, provided - I should have added - the new regime could be sustained.

There was also a lot of discomfort from the IMF side. They were informed of our decision to change the regime only on the night before. A telephone call from a high IMF executive waked me up in the dawn of January $13^{\text {th }}$. He was complaining of the decision. I read to him the following quotation from Fischer (1988), which I had on my bedside: "Devaluations, like visits to the dentist, are widely feared, are sometimes necessary, are generally put off longer than they should be, inflict pain for some time, and often do good" (p. 198).

He said this was a different situation and he predicted the new band would fail. I retorted that there was a probability of success equal to X, which was certainly higher than zero though we did not know its value. But I was sure $\mathrm{X}$ would be higher if we got immediate strong support from the IMF. He could not guarantee that. I said, "don't worry, if this fail I guarantee you we are going to float". I thought he wanted to be reassured capital controls and default were out of the question but, to my surprise, he sounded horrified. "If you float," he said, "you blow out all your neighbors." I asked what alternative he suggested, and he said, "set a bank holiday for tomorrow and fly to Washington". At this point I became horrified! All I could say was that a final decision had already been made by the President, and would be announced to the press in a few hours.

As it happened, no hint of support came from the IMF and the endogenous diagonal band lasted for only two days, the $13^{\text {th }}$ and $14^{\text {th }}$ of January. On the $15^{\text {th }}$ we stopped defending the $\mathrm{R} \$ 1,32$ ceiling and the market closed at $\mathrm{R} \$ 1,46$, around $10 \%$ above the ceiling. This last decision was somewhat premature and to a large extent the result of increased panic in the decision making group. It would have been wiser if we had maintained the defense until the weekend, when I was scheduled to fly with Malan to Washington for a meeting with the IMF. This way it would seem as if the decision to float had been taken in collaboration with the Fund, easing some of the already obvious discomfort.

An interesting counterfactual question is whether the band regime could be sustained and for how long. International reserves at the end January $12^{\text {th }}$, just before the regime change, were US\$ 41.49 billions. Two days later they were down by US $\$ 4.8$ billions, to US $\$ 36.69$, but only US $\$ 2.8$ billions represented 
effective capital outflows. Banks operating in the inter-bank currency market had taken a speculative position of around US\$ 2 billions, betting on further devaluation. At that point, however, they were already close to their maximum allowed position and it is not clear they would be willing to increase their speculative positions.

It is possible that the loss of reserves would go down over the following days if government could show a strong commitment to the new regime. A strong interest rate increase would have helped, but the truth is that our morale at that point was too low for a decisive defense of any exchange rate ceiling. We already knew from our previous experience that the defense of a currency peg is a painful, hopeless fight. For me, if government wanted an immediate float, with no more intermediate steps, that was fine. I had always believed that free floating is the ideal exchange rate regime. Free floating was announced as the new exchange rate regime on January $18^{\text {th }}$. Our discussion with the IMF over the weekend had been tense and conflictive, as they initially wanted us to introduce a currency-board. We had to explain that this was not a feasible proposition for Brazil, which have always had a very low degree of dollarization in its financial system. A compromise was finally reached on a floating exchange rates plus an inflation targeting system for monetary policy.

However, when we came to discuss details, I was astonished by the degree of control demanded by the IMF over our policy making decisions, as can be seen from the text in Appendix B we were given in Washington. For no particular reason they wanted us to scrap our TBC/TBAN system, which had been inspired on the Bundesbank tradition, putting in place a system tailored on FED tradition. ${ }^{27}$ And Mr. Candessus became very upset when I refused to raise the SELIC interest rate from the current level of $30 \%$ to $35 \%$ "at the opening of business on January 18,1999 ". Since it was a Sunday and I was in Washington, a virtual COPOM meeting would have to be held by means of overseas telephone calls. And I really could not see the point of such an awkward policy move, just "to show to the market that I was a though central banker", as I was told.

As a matter of fact, we held a COPOM meeting on Monday, January 18 and moved the SELIC rate to $32 \%$ on January 19 , starting a gradual movement upwards.

The rate reached $39 \%$ on the $1^{\text {st }}$ of February, the last day of my short tenure as Central Bank President. It remained at this level until March 3, 1999, when it was again raised to $45 \%$. In retrospect, our monetary policy was operated very much as demanded by the IMF in their "Understandings" proposal, without scraping the TBC/TBAN system or making bravados to the market. It is hard to understand why we were so utterly unable to reach a decent understanding at that time.

27 This came to happen in the beginning of March 1999. 
Figure 7: Interest rate policy and the exchange rate after the float

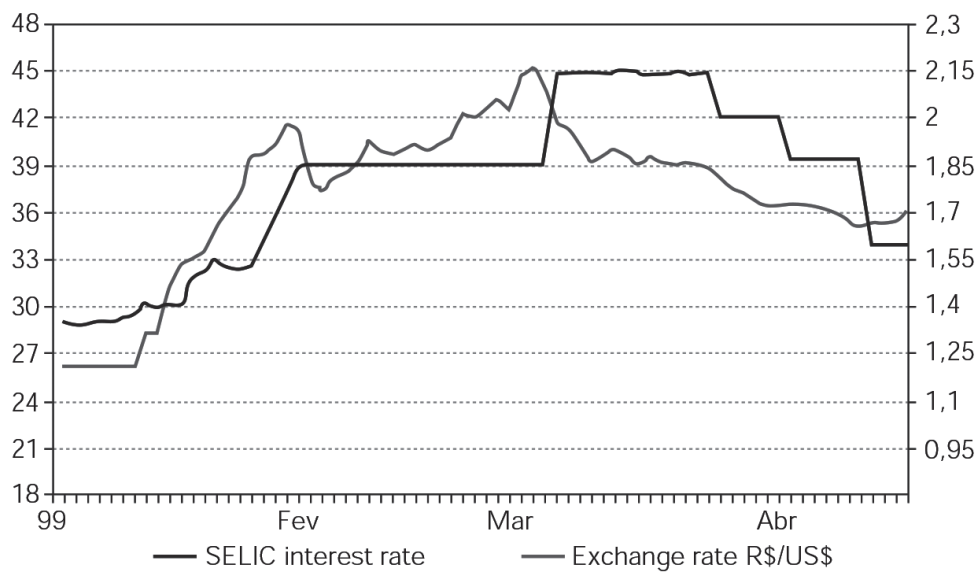

\section{CONCLUSION: A NICE AND EASY FLOAT}

The Brazilian float of January 1999 was a very benign event, denying all the expectations of disaster based on the experience of other emerging economies. There was no banking crisis, ${ }^{28}$ no collapse in derivative markets and no relevant business failures. There was no recession. GDP growth, which had been only $0.22 \%$ in 1998 as a consequence of the tight monetary policy, moved to $0.79 \%$ in 1999 and to $4.46 \%$ in 2000 . The inflation pass-through was small. Though the R \$/US\$ exchange increased $78 \%$ in the first 45 days of floating, and still showed a devaluation of $48 \%$ in the first year of floating, CPI inflation increased by only 7 percentage points, reaching $8.95 \%$ in 1999 and going down to $5.97 \%$ in 2000 . There was a $50 \%$ increase in foreign direct investment, which reached US\$ 30 billions in 1999 and 2000, equivalent to approximately 5\% do GDP. The main cost was an increase in the net debt of the consolidated public sector by 7 percentage points of GDP, from $42.3 \%$ of GDP in December 1988 to $49.4 \%$ of GDP by the end of $1999 .{ }^{29}$ This however has to be balanced against the possibility of future reductions in real

\footnotetext{
28 The bank restructuring program, PROER, implemented in 1996-97 was an important determinant of this, making sure that we had a relatively healthy banking system in 1998-99. Also important was the large, almost unlimited, supply of hedge by government, either through dollar indexed public bonds or through the selling of dollar futures. This reduced the risk of business failures due to large, un-hedged, private dollar debts.

${ }^{29}$ This debt figure is net of foreign reserves but includes the monetary base. The consolidated public sector includes federal government, social security, states and municipalities and state enterprises for all levels of government. The net debt of the consolidated public sector had climbed to $57 \%$ by November 2002 but this additional increase of 7.5 percentage points was more a result of post-float problems (including the crisis in Argentina and the presidential election of 2002) than a direct consequence of the float itself.
} 
interest rates, as monetary policy would no longer have to be used in extreme movements to defend the currency peg.

It is hard to know exactly why the Brazilian float was so benign. A key factor was probably the huge amount of hedge that was supplied by the Brazilian government before the float. This, as mentioned above, had a significant, but once and for all, fiscal cost in terms of increased public sector debt. And by allowing the private sector of the economy to be almost fully hedged, it avoided the deterioration of corporate and banks balance sheets that often produces credit crunch and recession on the wake of devaluation.

Also important in the Brazilian case was the intense de-indexation effort made in the years of 1995-1998. This, in conjunction with tight monetary policy, produced an annual CPI inflation of just $1.65 \%$ in 1998 and is most likely one of the reasons for the reduced pass-through of exchange rate devaluation on the rate of increase of prices.

An additional positive factor in the Brazilian float was the absolute respect for rules and contracts in spite of the foreseeable negative repercussions of the float on inflation and the public finances. The government, who had a large short position in dollar futures and dollar linked debt, honored the windfall losses resulting from the exchange rate devaluation without falling in the temptation of bending the rules to avoid payment or taxing speculators profits, as has often happened in the past (in our 1973 devaluation, for example) or in other countries. The concern of the Brazilian Central Bank with producing a smooth, uneventful, transition was so strong that it sold dollar futures on the eve of the float in order to eliminate any risk of collapse in the derivatives market. ${ }^{30}$

In January 1999 Brazil was at a crossroads where it had to decide between an exchange rate float and a return to a regime of Central Bank monopoly in foreign currency operations. This sort of centralized exchange transactions regime had been the rule in Brazil since the 30's and was only gradually eliminated since the early 90's. In 1998 many mechanisms of capital control were still in operation, tough banks and corporations had considerable freedom for international capital movement. But the bureaucracy was still there, and could be easily used for an immediate return to full foreign currency centralization. The inevitable consequences of such a policy move would be a complete cessation of capital inflows in the short term, a huge cash flow problem in foreign currency and an inevitable default and

\footnotetext{
${ }^{30}$ A Central Bank operation in the dollar futures market on January 14 was instrumental in supplying hedge for two small but highly speculative banks that would otherwise be unable to honor a huge volume of contracts, creating a potentially disruptive confidence crisis in one of Brazil's major hedge supplying mechanism. If they had defaulted, with the movement of the exchange rate up to the end of February the Brazilian Mercantile and Futures Exchange (BM\&F) would have collapsed as it lacked guarantees and net worth sufficient to honor margin adjustments of the order of US\$ 1500 millions. The Central Bank forced both banks to close but members of the Central Bank board at the time, myself included, have been indicted in a dozen of administrative and criminal lawsuits related to this operation. It has been a difficult task to make lawyers and judges understand the potential damage that could result from the collapse of a key derivative market during the transition to a floating exchange rate regime.
} 
restructuring of external debt. It would damage Brazil's international standing, hurt foreign direct investment and international commerce, and abort the still incipient process of integration of Brazil's economy to the world economy.

If the decision to float is compared to this counterfactual alternative of capital controls and default, with a focus on their long run consequences, the cost-benefit analysis will be overwhelmingly favorable. If we knew that an exchange rate float could be so benign, we would have done it earlier and with much less hesitation. But the real world has a way of teaching economists to be humble in applying their craft to policy making.

\section{APPENDIX A: THE ENDOGENOUS DIAGONAL BAND}

An exchange rate band is an attempt to have a compromise between the classic polar solutions of fixed and flexible rates. The objective is to have some degree of flexibility, as the rate is allowed to move freely within the lower and upper limits of the band, but also, at the same time, some degree of predictability, as the rate cannot move beyond these limits. This would be the ideal solution if we could guarantee that the market clearing exchange rate is always inside the band.

For all practical purposes, exchange rate bands collapse into fixed pegs when the market clearing rate moves beyond its limits. In this case the central bank will have to intervene continually, as the rate will be permanently trying to break one of the limits. It will require a policy response, either through an interest rate change to defend the band or by moving it upwards or downwards.

A troublesome situation typically occurs when the exchange rate gets close to the upper-limit. The market may attack the band, taking speculative positions in anticipation of an upward shift. The central bank will have to choose between a strong interest rate increase, in order to convince speculators that it will not move the band at this time, or an outright surrender to market pressure, letting speculators take their profit. Often the interest rate response will work only for a limited amount of time. Either solution may be costly to government in terms of public debt and reputation. Indeed, the record of band regimes is filled with episodes of disruptive band shifts.

One way to reduce the trouble of band shifts is to use a diagonal band, in which the limits increase overtime. The speed of diagonal movement may be fixed for a certain period of time, with regular revisions. This is particularly useful when there is inflation going on as shown by the experience of Israel, Poland and others (Eichengreen 1997). In the case of Israel, the band was not only diagonal but also widened overtime, aiming at a smooth gradual transition to free floating.

There is however a problem with the diagonal band. When market pressure makes the exchange rate move along the ceiling of the band, the regime becomes equivalent to a crawling peg, with a fully predictable rate of devaluation. If this rate is $\mathrm{T} \%$ per period, and the foreign interest rate is $\mathrm{F} \%$, the domestic interest rate will have to be larger than $(\mathrm{T}+\mathrm{F}) \%$ just to avoid arbitrage. Hence, defending a di- 
agonal band under pressure will require a larger interest rate because one has to take into account the predictable movement of the band. From this point of view, a horizontal band is less costly to defend than a diagonal band.

From this analysis, we conclude that the ideal band regime should have the following features:

a) It must widen over time, to allow a smooth gradual transition to free floating;

b) It must have a diagonal movement, in order to minimize the risk of disruptive band shifts;

c) Its diagonal movement must slow down when the band (ceiling) is under attack, so as to reduce the interest rate cost of defending it.

The endogenous diagonal band introduced by Brazilian Central Bank on January $13^{\text {th }} 1999$, had all these features. It had difference equations determining the changes of the ceiling $(\mathrm{T})$ and floor $(\mathrm{P})$ of the band at intervals of three working days. The change of the ceiling (DT) was given by:

$$
\mathrm{DT}=[\mathrm{a} *(\mathrm{~T}-\mathrm{X})+\mathrm{b} *(\mathrm{X}-\mathrm{P})] /(\mathrm{T}-\mathrm{P})
$$

with $\mathrm{X}$ being the average exchange rate observed during the three days interval since the last correction. The fixed parameters were $\mathrm{a}=0.000857$ and $\mathrm{b}=0.000428$. Note that $\mathrm{a}=2 \mathrm{~b}$, approximately.

The change of the floor (DP) was given by a similar equation:

$$
\mathrm{DP}=\mathrm{b}^{*}(\mathrm{~T}-\mathrm{X}) /(\mathrm{T}-\mathrm{P})
$$

These equations implied different speeds of movement for the band depending on the relative location of the actual exchange rate within it. If the rate was on the floor, that is $\mathrm{X}=\mathrm{P}$, then $\mathrm{DT}=\mathrm{a}$ and $\mathrm{DP}=\mathrm{b}$. Note that we may measure the speed of widening of the band by the difference between the rates of change of the ceiling and the floor, that is:

$$
\text { DT-DP }=\mathrm{a}-\mathrm{b}=\mathrm{b} \text { (approximately) }
$$

On the other hand, if the rate was on the ceiling, that is $\mathrm{X}=\mathrm{T}$, then DT $=\mathrm{b}$ and $\mathrm{DP}=0$, and the speed of widening would be:

$$
\mathrm{DT}-\mathrm{DP}=\mathrm{b}
$$

From (3) and (4) we see that the difference equations were designed so that the widening of the band would proceed at the same speed in all cases.

Figure A1 bellow shows a simulation of how the band would move, starting from the initial position of $\mathrm{P}=1.20$ and $\mathrm{T}=1.32$ on January 13 th. The bolder lines represent the movement of floor and ceiling if the actual rate moved along the ceiling, the thinner lines represent the movement when the actual rate remains permanently at the floor. In the first year, the percentage rate of increase of the ceiling would be approximately $2.7 \%$ in the first case and $5.4 \%$ in the second. 
Figure A1: The endogenous diagonal band in operation: movement of the ceiling $(T)$ and floor $(P)$ when the market rate stays at the ceiling $(X=T)$ or at the floor $(X=P)$

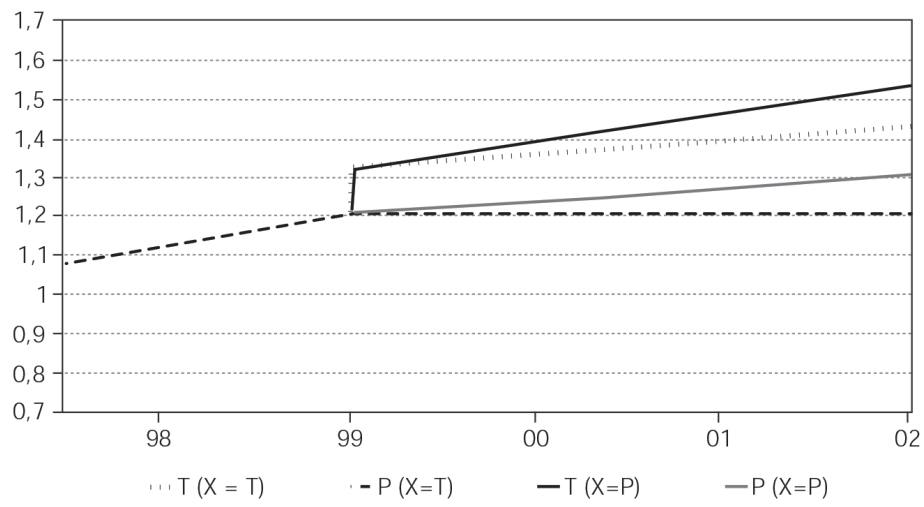

\section{APPENDIX B: UNDERSTANDINGS BETWEEN THE BRAZILIAN GOVERNMENT AND IMF MANAGEMENT REGARDING THE EXCHANGE RATE AND MONETARY POLICY FRAMEWORK IN BRAZIL UNTIL THE END OF FEBRUARY 1999}

\section{Foreign exchange intervention rules}

- Spot market. The Central Bank will not reduce its gross international reservesin excess of US\$500 million during any 5 consecutive business days or US $\$ 1$ billion during any 20 consecutive business days. When the currency is appreciating, it is expected that the policy response will entail a mix of interest rate reductions and a rebuilding of reserves.

- Futures and forward markets. The Central Bank will no longer intervene inforeign exchange futures markets and will not enter into foreign exchange forward contracts. The current exposure in the foreign exchange futures market will be reduced to zero following the expiration of existing contracts.

\section{Interest rate management rules}

- The TBC/TBAN system will be suspended as of the opening of business onJanuary 18, 1999

- Monetary policy will aim at preserving low inflation. To achieve this goal interestrate policy will be actively used to counter volatility and prevent an excessive depreciation of the exchange rate. At the opening of business on January 18, 1999, the Central Bank will conduct operations in the interbank markets so as to increase the annualized overnight interest (SELIC) rate to 35 percent. If thereafter, the exchange rate remains within a range of $\mathrm{R} \$ 1.40 /$ US\$ to R \$1.50/US\$, the Central Bank will intervene in the interbank market so as to keep the SELIC rate at that level. 
- Interventions in this market will be carried out so as to progressively increasethe SELIC rate the more the exchange rate exceeds R $\$ 1.50 / \mathrm{US} \$$. Conversely, Central Bank interventions may be carried out so as to gradually reduce the SELIC rate when the exchange rate falls below $\mathrm{R} \$ 1.40 / \mathrm{US} \$$. The SELIC rate will not be reduced during 3 consecutive business days following any business day when gross international reserves have declined. After a period of time in which the foreign exchange rate has remained stable, the exchange rate range mentioned above may be reset around the prevailing rate. The interventions required under these rules will be effected at the opening of the market on each business day following relevant movements in the exchange rate.

\section{Consultation rules}

In accordance with the stand-by agreement, either side is free to consult at any time. Until mutually agreed with Fund management, the authorities will consult with IMF staff at the close of each business day.

\section{REFERENCES}

BACHA, Edmar (2001) "Brazil's Plano Real: A View from the Inside," October 2001

Deutsche Bundesbank. 1995. The Monetary Policy of the Bundesbank

DIAZ ALEJANDRO, Carlos (1985) “Latin American Debt: I Don't Think We Are in Kansas Anymore”. Brookings papers on Economic Activity. 1985:2

EICHENGREEN, Barry, MASSON, Paul and BREDENKAMP, Hugh (1997) Exit Strategies: Policy Options for Countries Seeking Greater Exchange Rate Flexibility. International Monetary Fund, Washington, D.C. December 1997.

FISCHER, Stanley (1988) "Devaluation and Inflation" in R. Dornbusch and F. Leslie Helmers (eds), The Open Economy: Tools for Policymakers in Developing Countries. Oxford University Press: 108127.

FISHLOW, Albert (1974) "Indexing Brazilian Style: Inflation without Tears." Brookings Papers on Economic Activity 1: 261-80.

FRANCO, Gustavo B. F. (2000) “The Real Plan and the Exchange Rate." Essays in International Finance. $\mathrm{n}^{\circ} 217$, International Finance Section, Princeton University,

GORDON, Lincoln (2001) Brazil's Second Chance: En Route toward the First World. Brookings Institution Press.

HKMA (1995) Money and Banking in Hong Kong. Hong Kong Monetary Authority.

LOWENSTEIN, Roger (2000) When Genius Failed: the Rise and Fall of Long-Term Capital Management. Random House New York.

OBSTFELD, Maurice and ROGOFF, Kenneth (1995) “The Mirage of Fixed Exchange Rates”. Journal of Economic Perspectives. Fall 1995: 73-96

ROUBINI, Nouriel Chronology of the Asian Currency Crisis and its Global Contagion. Available in http:/ /www.stern.nyu.edu/globalmacro/AsiaChronology1.html.

SIMONSEN, Mario (1986) "Indexation: Current Theory and the Brazilian Experience." In Rudiger Dornbush and Mario Simonsen, eds, Inflation, Debt, and Indexation. Cambridge, Mass: MIT Press.

YAM, Joseph (1998) “Coping with Financial Turmoil”. Speech at Inside Asia Lecture 1998. Available in http://www.info.gov.hk/gia/general/199811/23/1123153.htm. 